DOI: 10.2478/v10122-009-0005-y

\title{
THE FORMATION OF THE DEFINITE ARTICLE IN THE NORDIC LANGUAGES
}

\author{
DOMINIKA SKRZYPEK
}

\begin{abstract}
Dominika Skrzypek. The Formation of the Definite Article in the Nordic Languages. Lingua Posnaniensis, vol. LI/2009. The Poznań Society for the Advancement of the Arts and Sciences. PL ISSN 0079-4740, ISBN 978-83-7654-080-1, pp. 65-76

The definite article in Modern Nordic languages is a suffix, etymologically related to a demonstrative. The form is not attested in the oldest linguistic sources, the runic inscriptions, but appears first in Icelandic sagas and Swedish and Danish legal codices from 13th century onwards. In these texts it does not appear with the same regularity as in modern languages.

Despite numerous attempts to reconstruct the formation of the definite article in the Nordic languages, a number of questions remain either controversial or unanswered. The contention issues are the exact etymology of the article and the date of its formation.

The demonstrative from which the article grammaticalizes appears in Old Icelandic in two forms: inn or hinn, in Old Swedish as hinn only. However, only inn appears as a clitic. It is argued here that the etymology of inn and hinn may provide an argument in favour of an early formation of the article.
\end{abstract}

Dominika Skrzypek, Department of Scandinavian Studies, Adam Mickiewicz University, al. Niepodległości 4, PL - 61-874 Poznań

\section{INTRODUCTION}

Among Indo-European languages there is considerable variation as to the form and position of the definite article. The majority of the western European languages show a preposed free morph: English the, German der/die/das, French la. In some the article is a bound, postposed morph: Bulgarian -ta, Romanian -ul and Nordic languages -in/-it.

The formation of the definite article in Nordic languages has been an object of many studies (e.g. Delbrück 1916; de Boor 1922; Hodler 1954; Heinrichs 1954; Leiss 2000). There is a substantial disagreement as to the time of its formation, which in lack of extensive written sources remains a reconstruction. It predates the first Nordic texts in the Latin alphabet (13th century), it is uncertain by how much. Some authors assume the formation to have taken place a century or so earlier (NYGAARD 1966; NorEEN 1913), while others (DELBRÜCK 1916; NeCKel 1924) put it further back in time, before 800 AD, when a dialectal split divided the region into eastern and western branch (see 1). In the most recent account, SyRETT 2002, the dates are generously stated as 500-1100 AD. 
In the present article I would like to address the problem of the hitherto largely ignored variation in the demonstrative from which the definite article developed, its etymology and possible implications for the dating of the process.

\section{THE DEFINITE NPS IN NORDIC LANGUAGES}

Historically, the descendants of the Ancient and Old Nordic (200-450/500, 450/500-1100 respectively, BANDLE et al. 2002) form two groups: Eastern Nordic (Swedish and Danish) and Western Nordic (Icelandic, Norwegian, Faroese). The dialectal division, dated at ca 800 AD, is based on a number of phonological differences (e.g. retention of ON diphthongs in the western branch). By 13th century the isolation of Iceland and the Faroe Islands led to a breach within the western branch, with Norwegian more and more exposed to the influence of Danish. Modern Nordic languages are thus grouped into continental (Swedish, Danish, Norwegian) and insular ones (Icelandic, Faroese). There are substantial differences between the two groups, phonological, morphological and syntactic. The insular languages resemble the Old Nordic highly inflected system in that they retain four cases and complex verb morphology. The continental languages, on the other hand, show a radically simplified morphology.

The Nordic languages all possess a morphologically marked category of definiteness, though there are different noun phrase (NP) patterns. There are also several exponents of the category. As in other Germanic languages (including present-day German) there is the weak (definite) adjectival inflection, with its source in a determiner, which is attached to the adjective:

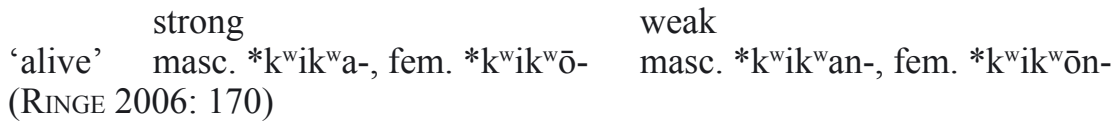

The meaning of the weak adjective is taken to be 'individualizing', definite, 'the one who has the quality' described by the adjective. The formation of the weak adjectival paradigm, dated to the PGmc period, is common to all Germanic languages, though it is now lost in English and Dutch. Two inflectional paradigms may be found in other Indo-European languages: Old Church Slavonic and in Serbo-Croatian, and, though limited to nom and acc sg masc, in Slovenian as well (KRÁMSKÝ 1974: 179-180).

Secondly, there is the definite suffix common to all Nordic languages, with the notable exception of the South Jutlandic dialects of Danish, which while possessing definite articles, have not developed a suffixed form (e.g. PERridOn 2002: 1019). The suffixed article is most commonly derived form a distal demonstrative pronoun $(h) i n n$ 'that'.

Moreover, all Nordic languages have developed a preposed definite determiner, resembling the English and German articles the, der/die/das. Etymologically, the form is derived from the demonstrative poen (originally accusative which substitutes the nominative sá) in the prepositional position. Its form is den in continental languages and tann in Faroese. In Icelandic hinn can occur in this position in very formal style.

Modern Nordic languages allow for different combinations of these definite exponents within one NP. In the examples below, two NPs, 'the man' and 'the old man', are given as they appear in all modern Nordic languages. 
Continental Nordic languages:

Swedish

(2)a. mannen

b. den gamla mannen

Danish (standard)

(3)a. manden

b. den gamle mand

Danish (South Jutlandic)

(3)c. æ mand

d. $\quad$ gamel mand

Norwegian (bokmål and nynorsk)

(4)a. mannen

b. den gamle mannen

Insular Nordic languages:

Icelandic

(5)a. maðurinn

b. gamli maðurinn / hinn gamli maður

Faroese

(6)a. maðurinn

b. tann gamli maðurinn

In the insular Scandinavian languages, where the category of case is fully productive, the definite article is inflected for case even when cliticized to the noun, which is also inflected. As a result, there are two case endings within each definite form.

(7)a. Icel. mann-s-in-s

man-GEN-DEF-GEN

Such a system is found in Old Swedish (1225-1541 AD) as well. For some paradigms the two endings are identical (ex. 7a), for some different (ex.7b):

b. ON/OS fisk-s-in-s

fish-GEN-DEF-GEN

from fisk 'fish', masculine a-stem

c. ON/OS bond-a-n-s / bónd-a-n-s

peasant-GEN-DEF-GEN

from ON bóndi, OS bondi 'peasant', masculine nd-stem

Since the definite form in modern insular languages as well as in ON and OS is only loosely attached to the noun, which retains its own inflection, it may more accurately be termed a clitic rather than a suffix (see Zwicky \& Pullum 1983 for a discussion on differences between clitics and affixes). However, in modern continental languages, where the 
case system has declined, the definite form is now suffixed directly onto the noun (MS: Modern Swedish):

(8)a.

MS fisk-en-S

fish-DEF-GEN

b.

MS bonde-n-s

peasant-DEF-GEN

The oldest Nordic sources are the runic inscriptions (the oldest are dated to the 3rd century). The oldest text written in the Latin alphabet is a fragment of a religious legend, written in Norway ca 1150. The first longer texts, dating from the 13th, are the Icelandic sagas in the western branch and legal codices in the east.

There are no definite forms of nouns in the runic material older than 1000 AD. Single occurrences of definite forms are noted from the period 1000-1200. Even in younger inscriptions, where other texts exhibit a plethora of definite forms, the article occurs only sporadically in runic inscriptions, which might suggest that it never was fully represented in this particular text genre (e.g. NECKEL 1924).

Both in sagas and in legal texts the definite forms are to be found with increasing frequency, though their distribution is much more limited and their occurrences still sporadic in comparison with the modern languages. There is a dramatic difference between different genres: whereas there are hardly any definite forms in the legal texts, they are abundant in somewhat younger religious prose, mainly inspired by Latin texts. Modern legal prose still uses the article diffidently in comparison with other genres (GUNNARSSON 1982). For Icelandic poetry it has been observed that the article is almost absent from the Edda with the exception of one part of it, Hárbarðsljóð, where its use overlaps to a great extent with the modern one. This difference in the distribution has again been ascribed to genre and style rather than chronology: this is the only part of an otherwise solemn text which records colloquial speech and dialogue (NECKEL 1924). That would point towards the definite article's being well-established in the spoken language even at a time when it is only poorly represented in texts.

Despite its low frequency, the form is attested for all genders, cases and numbers (examples in table 1 from Old Swedish), though all plural forms are far less frequent than the singular ones and some, particularly the genitive plural, are only sporadically found in the material.

Table 1. The definite nouns in Old Swedish

\begin{tabular}{|c|c|c|c|c|}
\hline & $\begin{array}{c}\mathrm{m} \\
d a y\end{array}$ & $\begin{array}{c}\mathrm{f} \\
\text { journey }\end{array}$ & $\begin{array}{c}\mathrm{n} \\
\text { ship }\end{array}$ \\
\hline \multirow[t]{4}{*}{ sg } & nom & daghr-in & færp-in & skip-it \\
\hline & gen & daghs-ins & færp-inna(r) & skips-ins \\
\hline & dat & daghi-num & færp-inne & skipi-nu \\
\hline & acc & dagh-in & færp-ena & skip-it \\
\hline \multirow[t]{4}{*}{$\mathrm{pl}$} & nom & dagha-ni(r) & færpe-na(r) & skip-in \\
\hline & gen & dagha-nna & færpa-nna & skipa-nna \\
\hline & dat & daghum-in & færpom-in & skipum-in \\
\hline & acc & dagha-na & færbe-na(r) & skip-in \\
\hline
\end{tabular}




\section{THE CLITICIZATION OF THE DEMONSTRATIVE}

As in many other languages, the source of the definite article is a distal demonstrative pronoun. In the Nordic languages its form and position (postposed bound morph) suggest the original constituent order noun + demonstrative.

In morphology, a bound morpheme derives historically from a free lexical or grammatical morpheme and generally inherits the same order relative to its stem that was assigned to the earlier free morphemes by syntax. (Hawkins 1990: 102-103).

The demonstratives in ON may appear on both sides of the noun, seemingly without a difference in meaning. However, only sá and sjá (benne) appear with nouns, whereas (h)inn is only found with weak adjectives: (h)inn $+\mathrm{A}$, sá/sjá $+\mathrm{N}$.

Two reconstructions of the cliticization process have been proposed in the literature. The first, given in GrImm 1837, is further developed in DeLBRÜCK 1916. To account for the demonstrative (h)inn as the source of the definite suffix, it assumes the postposition of an adjective phrase consisting of a weak adjective and a demonstrative:

maðr inn gamli man that old-DEF

The demonstrative, which originally belonged with the weak adjective, cliticizes onto the noun and comes to be reanalyzed as its affix, allowing nouns to appear without the adjective. The theory is identical with the reconstruction proposed for Rumanian ('homo-illebonus' e.g. GRAUR 1967: 22), which was possibly inspired by the Nordic one.

Later statistical studies have shown that the frequency of such phrases might be lower than previously assumed, and of the phrases that are found, the crashing majority consist of a proper name rather than a common noun, as in e.g. Haraldr inn hárfagri 'Harald the fairhaired' (Musinowicz 1911 gives 98 out of 102 instances), which undermines the reconstruction. Therefore, a postposition of the demonstrative, with possible anaphoric reference, has been proposed by e.g. NYGAARD (1966: 34) and accepted by many others (e.g. LARM 1936). However, throughout the texts, proper names with a cliticized demonstrative are also found, as Erikinum hoelghce 'Erik-DEF holy-DEF'. Another argument in favour of the Grimm hypothesis is that it brings together the two exponents of definiteness in ON: the weak adjective and the clitic. A reconstruction whereby a postposition of a demonstrative by itself is assumed leaves out weak adjectives with their definite meaning. It would mean that alongside one exponent of definiteness, another one was being formed. The evidence available today shows that the two exponents are used in identical contexts. Therefore it is reasonable to look for a structure which may bring together the postposed demonstrative and the weak adjective.

In later stages of the development a third exponent arises, the preposed definite determiner pen. However, in this case grammaticalization takes place in contexts previously not marked by any definite form, the distribution of -inn and pen being originally close to complementary. The preposed determiner pen was used mainly in anaphoric contexts, when the same referent was mentioned again, necessarily in a neighbouring syntagm. The developing definite article -inn on the other hand was used in so-called associative-anaphoric contexts, with the referent familiar due to previous mention of other, related referent. This difference is illustrated by examples below, taken from the oldest Swedish text, Äldre Västgötalagen. 
(10) Varpær supærman dræpin allær ænskær mapær. pa skal böta firi marchum fiurum. pem sakinæ sökir. ok tvar. marchar konongi. (ÄVL aM:5)

be southerner killed or Englishman then shall pay for marks-DAT four-DAT the-DAT charge-DEF-ACC searches and two marks king-DAT

'If a German is killed, or an Englishman, the crime is paid with four marks to the one pressing charge and two to the king'

(11) Læggær mapær manni fæ sit in til gætslu. pa ma pæt fæe eigh tapas af pem uip takar (ÄVL RB: 13)

puts man-NOM man-DAT cattle his in for safekeeping then may the cattle not lost (be) of the-DEF takes

'If a man gives his cattle another man for safekeeping then the cattle may not be lost by the keeper'

No similar systematic distributional differences between the weak adjective and the definite clitic have been found.

\section{THE ETYMOLOGY OF THE NORDIC ARTICLE}

The demonstrative pronoun $(h)$ inn is found in the eastern languages (Swedish and Danish) almost exclusively as hinn (there are five runic inscriptions where the form inn appears, U 226, U 1146, Hs 21, Sö 41, Sö 125, see Rundatabasen), whereas in Icelandic two forms are in variation: hinn and inn/enn. There they seem to be interchangeable in all contexts, though a more detailed study is called for.

(12)a. hit fyrra sumar

'the.NEUT previous summer'

b. $\quad$ et sama kveld

'the.NEUT same evening'

c. Haraldr hinn hárfagri

'Harald the.MASC fair-haired'

d. Hákon jarl enn ríki

'Hakon earl the.MASC rich'

(NYGAARD 1966: 49-50; FAARLUND 2004: 58)

This variation in form has not been given sufficient prominence in the literature, though in most works it is tacitly assumed that hinn and inn are the same pronoun, inn being the weakened one. In the following we will take a closer look at the demonstratives found in ON and OS and their etymologies.

The ON demonstrative system as reconstructed today encompasses following pronouns: sá, sjá (OS pcenne), hinn and inn/enn (not attested in OS). All of the elements contain some reference to the distance between the speaker and the object, though what exactly is a disputable matter. The reason for it is first and foremost the insufficiency of sources which do 
not allow for sweeping generalizations. It is also possible that the proximal/distal contrast was not of equal prominence in all contexts and many contexts would allow for any of the demonstratives to be used.

In runic inscriptions, which are the oldest linguistic sources from Scandinavia, both sjá and $s a ́$ are found, in seemingly identical contexts, either preceding or following the noun, typically stein 'stone' on which the inscription is carved.

(13)a. pat azina (By stone, ca $500 \mathrm{AD}$, Norway)

'this stone slab'

b. $\quad$ stein saR (U 10)

'stone this'

c. poriR ok hroða letu ræisa stæin pennsa (U 429)

'Thore and Hroda had this stone raised'

d. astrið let raisa penna stæin (U 238)

'Astrid had this stone raised'

However, it must be noted that sjá is by far the most frequently used demonstrative, overwhelmingly postposed (PERRIDON 1995: 252), with few instances of sá and only sporadic use of hinn, as in the $500 \mathrm{AD}$ inscription from Norway, which supplies the first occurrence of adnominal hinn without a weak adjective:

(13)e. hali hino (Strøm whetstone, ca 500 AD, Norway)

'stone this'

(NIELSEN 2000: 173)

The common reconstructions would ascribe proximal deixis only to the compound demonstrative sjá (in OS sasi or later penne), whereas sá, hinn and inn are all translated as 'that' without further subdivisions (e.g. NygaARD 1966; NoreEn 1913). Their inflectional paradigms as found in Runic and Old Swedish are presented below. Apart from the lost diphthongs in e.g. pem (ON peim) they are identical with the $\mathrm{ON}$ ones. As can be seen, the paradigm of sá encomprises two IE demonstrative stems: ${ }^{*} t$ - and ${ }^{*} s$ - (in Polish ten/talto 'this' and $s$ - in do siego roku 'for the next year, happy new year' respectively). The $s$-forms, masculine and feminine nominative, are abundant in runic inscriptions but in classical Old Swedish (1225-1375) they give way to the accusative pen and $p a / b e$.

Table 2. The paradigm of the demonstrative sá

\begin{tabular}{|l|l|l|l|l|}
\hline \multicolumn{2}{|c|}{} & \multicolumn{1}{|c|}{$\mathrm{m}$} & \multicolumn{1}{c|}{$\mathrm{f}$} & \multicolumn{1}{c|}{$\mathrm{n}$} \\
\hline \multirow{4}{*}{ sg } & nom & sá & sú & pæt \\
\cline { 2 - 5 } & gen & pæs & per(r)a & pæs \\
\cline { 2 - 5 } & dat & bem & per(r)e & by \\
\cline { 2 - 5 } & acc & pæn & pá & pæt \\
\hline \multirow{4}{*}{ pl } & nom & per & par & pen \\
\cline { 2 - 5 } & gen & pera & pera & pera \\
\cline { 2 - 5 } & dat & pem & pem & pem \\
\cline { 2 - 5 } & acc & pe & par & pen \\
\hline
\end{tabular}


Ta b le 3. The paradigm of the demonstrative sjá (pcenne)

\begin{tabular}{|l|l|l|l|l|}
\hline \multicolumn{2}{|c|}{ sg } & \multicolumn{1}{|c|}{$\mathrm{f}$} & \multicolumn{1}{c|}{$\mathrm{n}$} \\
\hline \multirow{5}{*}{} & nom & $\begin{array}{l}\text { pænne } \\
\text { sā(R)si }\end{array}$ & pæsse & pætta \\
\cline { 2 - 5 } & gen & pæssa & pæssa & pæssa \\
\cline { 2 - 5 } & dat & pæssom, pæmma & pæsse & pæsso \\
\cline { 2 - 5 } & acc & pænna & pæssa & pætta \\
\hline \multirow{3}{*}{ pl } & nom & pæssi(r) & pæssa & pæssi(n), pænne \\
\cline { 2 - 5 } & gen & pæssa & pæssa & pæssa \\
\cline { 2 - 5 } & dat & pæssom & pæssom & pæssom \\
\cline { 2 - 5 } & acc & pæssa & pæssa & pæssi(n) \\
\hline
\end{tabular}

Ta b le 4. The paradigm of the demonstrative hinn

\begin{tabular}{|l|l|l|l|l|}
\hline \multicolumn{2}{|l|}{} & \multicolumn{1}{|c|}{$\mathrm{m}$} & \multicolumn{1}{c|}{$\mathrm{f}$} & \multicolumn{1}{c|}{$\mathrm{n}$} \\
\hline \multirow{4}{*}{ sg } & nom & hinn & hin & hitt \\
\cline { 2 - 5 } & gen & hins & hinna(r) & hins \\
\cline { 2 - 5 } & dat & hinom & hinne & hino \\
\cline { 2 - 5 } & acc & hinn & hina & hitt \\
\hline \multirow{4}{*}{ pl } & nom & hinir & hinar & hin \\
\cline { 2 - 5 } & gen & hinna & hinna & hinna \\
\cline { 2 - 5 } & dat & hinom & hinom & hinom \\
\cline { 2 - 5 } & acc & hina & hinar & hin \\
\hline
\end{tabular}

The retention of the case inflection of the pronoun allows us to narrow the field of possible candidates for the article to hinn and inn (see also Table 1).

Havir konæ hor giort ok givær bondæ kono sinni sak. pa væri sik. mæp siv mannum af næmdinni. (ÄVL GB: 5)

has woman-NOM adultery done and gives husband-NOM wife-DAT his-DAT charge than defends herself with seven man-PL-DAT of jury-DEF-DAT

'If a woman has committed adultery and the husband charges her with it, she should defend her case with the testimony of seven men of the jury'

The disagreement reduces as to whether the two are indeed separate pronouns with separate etymologies or whether they are just two forms of the same pronoun. Among the proponents of the latter view a rift occurs whether hinn or inn is the original one.

The pronoun inn is a descendant of the PIE demonstrative *eno, compare e.g. English yon, Gothic jains or Ancient Greek *(e)ke-eno-s. For some of the proponents of common etymology of inn and hinn, hinn is a continuation form, 'strengthened' by a deictic element $h$-. The $h$-itself may be a descendant of PIE $* k$-, an item of weak there-deixis, related to $h$-in English he/him, Dutch hij, Nordic han/hon. Such is the view presented in KRAHE (1967: 56, 67). All authors assuming the composition of the demonstrative hinn regard inn as the original form, see Noreen (1913: 180, 190), DE Boor (1920: 173, 178), KrAHE (1967: 67), and lately SYRETT (2002: 721). 
The opposite view, as presented in among others Jónsson (1921: 315) and NECKEL (1924: 407-412), assumes a phonetically conditioned $h$-drop and thus hinn as the original form and inn as the shortened one. This etymology is more problematic as no direct PIE descendant of hinn can be found. Neckel would see a relative in the Greek demonstrative kẽinos 'that'. It is to be noted that this particular demonstrative is a compound of PIE $* k$ - and $* e n o-$, in other words, exactly the form postulated for hinn by e.g. Krahe, comp. Ancient Greek form quoted above, *(e)ke-eno-s (see Рвокоsсн 1939: 272-273).

To my knowledge the only proposal of a different form as the source of the article is GJERDMAN 1924. Gjerdman's hypothesis rejects hinn as the source of the definite article, and instead seeks its etymology in the personal pronoun hann 'he', which etymologically also derives from PIE deictic stems $* k$ - and $* e n o$. As fas as I know, his theory has only been taken seriously by one author, PERRIDON 1989. Despite the etymological relation between the two, a serious challenge to it is presented by the paradigm of the pronoun, particularly the neuter form, $p e t$, which in the dative was $p y$, whereas the clitic is clearly derived from hitt, of which the dative form is hino.

OS a cors-e-n-o on cross-DAT-DEF-DAT

Typologically, the most usual course of action is the grammaticalization of the distal demonstrative to the definite article. It is usually the distal demonstrative that is the unmarked in a pair proximal - distal. However, if the proximal one should be the unmarked one of the pair, it is more likely to appear in article-like contexts. In Polish, for instance, which lacks a definite article, a demonstrative ten/ta/to 'this near me' may be used in article-like functions (as well as older ów/owa/owo 'that') but never tamten/tamta/tamto 'that away from me', e.g.

(16)a. Przyjęto pewną teorię. Teoria ta... (possibly Ta teoria...)

A theory was accepted. The (This) theory...

b. $\quad$ Przyjęto pewną teorię. *Teoria tamta... (and neither Tamta teoria...)

A theory was accepted. That theory...

The reason for it is that the proximal ten/ta/to is the unmarked demonstrative and the compounded distal tamten/tamtaltamto the marked one.

This leads us to conclude that the most likely candidate for the article is to be sought in a demonstrative with deictic force so weakened that its sole function is to point but not to give much information as to the distance to the object.

\section{THE AGE OF THE NORDIC ARTICLE}

This lengthy presentation of an etymological strife is relevant for further discussion of the origin and age of the article, as it seems that only inn is ever cliticized. No form with cliticized hinn has been found. 
(17)a. bondanom peasant-DAT-DEF-DAT

b. *bondahinom

That there is some relation between hinn and inn is beyond doubt. First of all, all reconstructions point towards PIE * eno for both forms. Secondly, their inflectional paradigms are identical. As for the initial $h$-, the proposal that it is there for phonological reasons finds little support in other linguistic data. In initial and medial positions $h$-was, if anything, prone to deletion rather than insertion. What remains as the most probable reconstruction is the blending of two elements, $h$ and inn. In that case the proposed $h$-drop seems quite improbable. If an element is attached to a demonstrative to strengthen it, what reasons would there be for it to be lost and with it the information it contained?

The variation between inn and hinn has not been considered of any consequence in the literature. Most of the authors seem tacitly to assume an $h$-drop in inn, ergo hinn as the original form, the one from which the definite article is formed. Nor has it ever been questioned why only inn cliticizes and never hinn.

In the process of grammaticalization, the clitic and the free morph are initially in free variation. However, with time two scenarios are feasible and attested in other grammaticalization processes: either the free form and the bound form split and develop independently of each other (as in e.g. Nordic -sk vs sik) or the free form disappears entirely. We know that the first scenario is the ON one, since inn survives alongside -inn.

Such examples illustrate the fact that the development of inn and -inn from some point follow separate paths. An additional complication is created by the complex form with $h$ -

Had the composition predated the cliticization, we would have two forms to choose from: the weakened inn and the reinforced hinn. The latter is the more likely candidate for cliticization. However, we can equally well assume that the composition follows the cliticization, perhaps even result from it. A weakened demonstrative is further undermined by its increasing bondedness with the noun. This becomes an opportune moment for reinforcement.

Since OS emerged devoid of the demonstrative inn entirely, while OI retains the two forms, we may conclude that their parallel existence belongs to a period of common history, before the dialectal split had taken place. This leads to a further possibility that since the inn that is the source of the -inn is not attested in any Swedish material, including runic inscriptions (with the exceptions mentioned above), the cliticization must predate the sources available to us today. Therefore the formation of the definite form belongs to ON period, before $800 \mathrm{AD}$.

\section{CONCLUSION}

In this article the history of the formation of the definite article in the Nordic languages was sketched with particular emphasis on its etymology. The demonstrative from which the article has developed appears in western Nordic languages as either inn or hinn, with the latter form most readily explained as a compound, strengthened by a deictic element $h$-, identical with that in personal pronouns han 'he' and hon 'she'. The composition of the de- 
monstrative is here seen as connected with its cliticization onto the noun. Though the exact order of events may not be reconstructed because of the lack of sources, an interdependence of the two processes explains why it is only the $h$-less form that was cliticized and why no instances of -hinn have ever been attested. The proposed connection between the two processes makes an early date of the cliticization a more plausible solution.

Such an early date, though already proposed by some scholars (DELBRÜCK 1916; NECKEL 1924), is seriously challenged by the fact that the earliest instances of the definite suffix come from a few debatable examples form the runic material and the twenty odd examples from Äldre Västgötalagen. The absence of definite forms may be explained by stylistic reasons, but perhaps even by the gradual acquisition of its functions, which lagged behind the formal development of the article.

\section{REFERENCES}

BAndLE Oskar et. al. (eds.). 2002. The Nordic Languages. Vol. 1-2. Berlin: Walter de Gruyter.

De Boor Helmut. 1922. Studien zur altschwedischen Syntax: in den ältesten Gesetztexten und Urkunden. Breslau: M \& M Marcus.

BRAUNMÜLLER Kurt. 1982. Syntaxtypologische Studien zum Skandinavischen. Tübingen: Narr.

Croft William, Denning Keith, Kemmer Suzanne (eds.). 1990. Studies in Typology and Diachrony for Joseph H. Greenberg. Amsterdam-Philadelphia: John Benjamins.

DeLbRÜCK Berthold. 1916. Der altisländische Artikel. Germanische Syntax III. Leipzig: Teubner.

FAARLUnd Jan Terje. 2004. The Syntax of Old Norse with a Survey of the Inflectional Morphology and a Complete Bibliography. Oxford: Oxford University Press.

GJERDMAN Olof. 1924. "Till frågan om bestämda artikelns uppkomst och placering" (On the Question of the Origin and Position of the Definite Article). Festskrift till H. Pipping. Helsingfors: Sv. litteratursällsk. i Finland.

Graur Alexandru. 1967. The Romance Character of Romanian. Bucharest: Publishing House of the Academy of the Socialist Republic of Romania.

GrImm Jacob 1898 [1837]. Deutsche Grammatik IV. Göttingen: Gütersloh.

GunNARSSON Britt-Louise. 1982. Lagtexters begriplighet: en språkfunktionell studie av medbestämmandelagen (Understandability of Legal Texts). Stockholm: LiberFörlag.

Hansen Aage. 1927. Bestemt og ubestemt substantiv (Definite and Indefinite Noun). Kopenhagen: Busck.

Hawkins John. 1990. "Seeking Motives for Change in Typological Variation.” In: Croft et al. 1990: 95-128.

HeINRICHS Heinrich. 1954. Studien zum bestimmten Artikel in den germanischen Sprachen. Giessen: Wilhelm Schmitz.

HODLER Werner. 1954. Grundzüge einer germanischen Artikellehre. Heidelberg: Winter.

JóNSSON Finnur. 1901. Det norsk-islandske skjaldesprog omtr. 800-1300 (The Norwegian-Icelandic Skaldic Language ca 800-1300). Köpenhamn: Samfundet til udgivelse af gammel nord.litteratur.

KRAHE Hans. 1967. Germanische Sprachwissenschaft II. Formenlehre. Berlin: Walter de Gruyter.

KrÁmSKÝ Jirí. 1974. The Article and the Concept of Definiteness in Language. The Hague: Mouton.

LARM Karl. 1936. Den bestämda artikeln i äldre fornsvenska (Definite Article in Classical Old Swedish). Stockholm: Bonniers.

Leiss Elisabeth. 2000. Artikel und Aspekt. Berlin: Walter de Gruyter.

LunT Horace 2001. Old Church Slavonic Grammar. Berlin: Mouton de Gruyter.

Musinowicz Alexander. 1911. Die Stellung des attributiven Adjektivs im Altisländischen und Altnorwegischen. Riga: N. Kymmel.

NeCKel Gustav. 1924. Die Entwicklung von schwachtonigem altnordischem u (o) vor m aus helleren Vokalen und der altnordische Substantivartikel. Festschrift für E. Mogk. Halle an der Saale: Niemeyer.

Nielsen Hans Frede. 2000. The Early Runic Language of Scandinavia. Heidelberg: Universitätsverlag C.Winter. NOREEN Adolf. 1913. Altnordische und altisländische grammatik. Halle: Niemeyer.

NygaARd Marius. 1966[1905]. Norrøn syntax (Old Icelandic syntax). Oslo: Aschehoug \& Co.

Отто́sson K. et. al. 1995. The Nordic Languages and Modern Linguistics 9. Oslo: Novus Forlag. 
PerRidon Harry. 1989. Reference, Definiteness and the Noun Phrase in Swedish. Doctoral dissertation, University of Amsterdam.

Perridon Harry. 1995. "Noun Phrases in Runic Swedish.” In: Ottósson et. al. 1995: 248-261.

PerRidon Harry. 2002. "Dialects and Written Language in Old Nordic II: Old Danish and Old Swedish". In: BanDLE et. al. 2002: 1018-1028.

Proкоsch Eduard. 1939. A Comparative Germanic Grammar. Philadelphia: University of Pennsylvania.

Ringe Donald. 2006. From Proto-Indo-European to Proto-Germanic. Oxford: Oxford University Press.

Rundatabasen: a corpus of Nordic runic inscriptions. $<$ http://www.nordiska.uu.se/forskn/samnord.htm>.

SPRENGER Ulrike. 1977. Untersuchungen zum Gebrauch von sá und nachgestelltem inn in der altisländischen Prosa. Basel: Helbing \& Lichtenhahn.

Steblin-KamenskiJ Michail. 1953. Istorija skandinavskich jazykov (The History of Scandinavian Languages). Moskva: Izdatel'stvo Akademii Nauk SSSR.

SyretT Martin. 2002. "Morphological Developments from Ancient Nordic to Old Nordic". In: Bandle et. al. 2002: 719-727.

Zwicky Arnold, Pullum G.K. 1983. "Cliticization vs Inflection: English n't”. Language 59(3), 502-513.

Runic examples are quoted after Rundatabasen. Old Swedish examples (10), (11) and (14) are from the oldest Swedish text, Äldre Västgötalagen, Older Law of Western Götaland, from 1225. 